\title{
ПРОФИЛАКТИКА НЕОПТИМАЛЬНЫХ МОДЕЛЕЙ СЕМЕЙНОГО ВОСПИТАНИЯ ДЕТЕЙ С ОВЗ
}

\section{PREVENTION OF SUB-OPTIMAL MODELS OF FAMILY UPBRINGING OF CHILDREN WITH HIA}

A. Dohoyan

Summary: The article considers the family as a system-forming determinant in the socio-cultural status of the child, predetermining its further psychophysical and social development. Based on the material studied, four options for the classification of "problem families» have been identified under different criteria. The subject of the study was the consideration of non-constructive models of family upbringing of children with HIA. Non-constructive models of family upbringing of a child with developmental disabilities create the prerequisites for the emergence of secondary abnormalities in his mental development, which have a significant impact on the intellectual and personal development of the child.

Keywords: family, family dysfunction, child with disabilities, family upbringing, unconstructive models of family child upbringing, troubled families.

\author{
Дохоян Анна Меликсовна \\ к.nсх.н., доцент, ФГБОУ ВО «Армавирский \\ государственный педагогический университет» \\ d.a.m@mail.ru
}

Аннотация: В статье рассматривается семья как системообразующая детерминанта в социально-культурном статусе ребенка, предопределяющая его дальнейшее психофизическое и социальное развитие. На основании изученного материала выделены четыре варианта подхода к классификации «проблемных семей», выделенные по различным критериям. Предметом исследования стало рассмотрение неконструктивных моделей семейного воспитания детей с ОВЗ. Неконструктивные модели семейного воспитания ребенка с отклонением в развитии создают предпосылки для возникновения вторичных отклонений в его психическом развитии, которые оказывают значительные влияния на интеллектуальное и личностное развитие ребенка.

Ключевые слова: семья, семейное неблагополучие, ребенок с ограниченными возможностями здоровья, семейное воспитание, неконструктивные модели семейного воспитания ребенка, проблемные семьи.

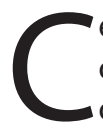
емья представляет собой первый социальный институт, в котором ребенок обучается приемам присвоения культурных ценностей. Именно в семье в сознании ребенка формируются представления о жизненных целях, нравственных ценностях, добре и зле, вырабатываются образцы поведения [5].

Существует прямая зависимость развития ребенка от семейного фактора: чем сильнее проявляется семейное неблагополучие, тем более выражены нарушения развития у ребенка. Семья, в которой есть ребенок с ограниченными возможностями здоровья, - это особый объект внимания всех специалистов, которые оказывают помощь семье [1,стр.123].

Российское законодательство закрепляет за родителями ответственность за воспитание своих детей (Семейный кодекс РФ, Федеральный закон «Об образовании в Российской Федерации»). В связи с этим возрастает и роль семьи в воспитании ребенка с ОВ3, что в свою очередь объясняет потребность родителей в различных реабилитационных мерах, направленных им в помощь для реализации этой задачи.

Современный подход к семье, воспитывающей ребенка с ограниченными возможностями здоровья (ОВ3), рассматривает ее как реабилитационную структуру, изначально обладающую потенциальными возможностями к созданию максимально благоприятных условий для развития и воспитания ребенка (С.Д. Забрамная, И.Ю. Левченко, Э.И. Леонгард, Н.В. Мазурова, Г.А. Мишина, Е.М. Мастюкова, Л.И. Солнцева, В.В. Ткачёва и др.).

Семья рассматривается как системообразующая детерминанта в социально-культурном статусе ребенка, предопределяющая его дальнейшее психофизическое и социальное развитие.

Предметом нашего исследования стало рассмотрение неконструктивных моделей семейного воспитания детей с OB3.

Неконструктивные модели семейного воспитания ребенка с отклонением в развитии создают предпосылки для возникновения вторичных отклонений в его психическом развитии, которые оказывают значительные влияния на интеллектуальное и личностное развитие ребенка.

Первый подход к классификации «проблемных семей, воспитывающих детей с ОВЗ» выделен на основании степени объективного риска социальной уязвимо- 
сти семьи, воспитывающей ребенка с ОВ3, в связи с её экономической нестабильностью.

В данную группу вошли исходно неполные семьи, в которых, с момента рождения ребёнка с ОВ3, его воспитывает один из родителей (законных представителей; многодетные семьи, в составе которых есть ребенок с OB3, попавшие в ситуацию экономической нестабильности; семьи беженцев и вынужденных переселенцев, в которых воспитывается ребенок с ОВ3; семьи безработных, имеющих на иждивении детей с ОВ3; семьи военнослужащих срочной службы с детьми, имеющими ОВ3; семьи разведённых родителей, в которых один их них уклоняется от выплаты алиментов на детей в целом, и на ребенка с ОВ3, в частности; семьи, в которых родителями являются инвалидами; семьи, воспитывающие опекаемых и усыновлённых детей с ОВ3; семьи, пострадавшие от последствий техногенных, природных, экологических катастроф; студенческие семьи с детьми, в т.ч. и детьми c OB3.

К числу первоочередных мер по профилактике неоптимальных моделей семейного воспитания и оказанию помощи семьям, входящим в первую группу, можно отнести следующие: оказание консультативно-организационной помощи в получении социальных льгот, пособий, кредитов, благотворительной и гуманитарной помощи; оказание консультативно-организационной помощи в трудоустройстве взрослых безработных членов семьи, а также несовершеннолетних, имеющих право на трудоустройство; содействие в получении льготных путёвок в детские оздоровительные учреждения для лечения или отдыха в летний период детей с ОВ3; организация благотворительных аукционов, ярмарок, выставок-продаж по сбору средств для оказания помощи экономически нестабильным семьям, в которых воспитываются дети с OB3.

Однако, решая проблему укрепления материального благосостояния семей, относящихся к первой группе, специалист должен обратить также внимание ни необходимость решения других проблем, свойственных отдельным семьям, которые могут спровоцировать факты семейного насилия в отношении детей с ОВ3, их безнадзорность, социальное сиротство.

В связи с этим некоторые типы семей будут повторяться в других классификациях, в целях обозначения комплекса характерных для них проблем и способов их решения.

Второй вариант подхода к классификации «проблемных семей», выделенный по критерию степени сохранности структуры семьи.

Это исходно неполные семьи, в которых с момента рождения ребёнок с ОВЗ воспитывается одним из ро- дителей (законным представителем); неполные семьи, появившиеся вследствие смерти одного из родителей (законных представителей), в которых воспитывается ребенок с ОВ3.; нуклеарные семьи, в составе которых есть дети с ОВ3; семьи, в которых родители находятся в повторном браке, и имеют детей с ОВ3; семьи, воспитывающие опекаемых и усыновлённых детей с ОВЗ и семьи, образовавшиеся в результате развода, воспитывающие детей с ОВ3.

Включение этих семей в категорию проблемных обусловлено тем, что только гармония отцовской и материнской любви; мудрая, щедрая на ласку, заботу, внимание любовь бабушек и дедушек, тёплые отношения с сестрами и братьями могут выступать надёжными гарантами счастливого детства любого ребенка, в том числе и c OB3.

К сожалению, в семьях с нарушенной структурой родители, воспитывающие ребенка с ОВ3, не в состоянии обеспечить эту гармонию по различным причинам.

В неполных семьях всех типов дети тяжело переживают отсутствие одного из родителей. Возможна ситуация, когда родитель, с которым проживает ребёнок, самоустраняется от выполнения родительских обязанностей, что ведет к безнадзорности, а также к социальному сиротству. Особое внимание специалисты «Службы сопровождения детей с ОВ3 и их семей» должны обратить на психологический микроклимат в неполных семьях, так как стрессообразующими факторами являются и смерть супруга, и развод, и одиночество, и стремление одного из родителей категорически запретить контакты с родителем, находящимся в разводе. В таких семьях дети очень часто выступают в несвойственной им роли «утешителя», «примирителя», «громоотвода»; проявляют склонность к различным проявлениям деструктивного и девиантного поведения.

В семьях, где воспитанием занимается только мать, велика угроза феминизации воспитания, если отец - маскулинизации.

Для семей, в которых родители находятся в повторном браке, часто характерна неприязнь отчима или мачехи к детям от первого брака, конфликты между сводными детьми, детьми, родившимися от повторного и предыдущих браков. Эти дети, в том числе и с ОВ3, очень часто становятся жертвами домашнего насилия со стороны членов семьи.

Наиболее типичной проблемой для нуклеарной семьи с детьми, в том числе и с ОВ3, является дефицит совместной деятельности, дефицит общения с другими членами семьи: бабушками, дедушками, родственниками по отцовской, материнской линии. 
В целях профилактики неоптимальных моделей семейного воспитания детей с ОВ3, и коррекции взаимоотношений в семьях с нарушенной или неоптимальной структурой необходимо оказывать правовую помощь родителям (законным представителям) в целях налаживания полноценных контактов с детьми; проводить групповые и индивидуальные консультации для родителей (законных представителей) из неполных семей; оказывать помощь детям и родителям (законным представителям) и в организации досуга, консультативно-организационную помощь по записи детей с ОВ3 в кружки, студии, спортивные секции, в целях преодоления дефицита общения в целом и межполового общения в частности, обращая при этом особое внимание их возрастные и индивидуальные особенности, обусловленные патологией психосоматического развития; содействовать в оказании квалифицированной психологической помощи родителям (законным представителям) и детям с ОВ3 в стрессовых и экстремальных ситуациях, таких как: повторный брак родителей, развод, смерть членов семьи.

Третий вариант подхода к классификации «проблемных семей» выделен на основании особенностей психофизического развития детей. Данная классификация непосредственно связана с необходимостью определения тяжести отклонений в психосоматическом развитии: семьи, воспитывающие одарённых и талантливых детей, имеющих отклонения в психосоматическом развитии; семьи, имеющие детей, страдающих хроническими соматическими заболеваниями; семьи с детьми, имеющими нарушения интеллектуальной, сенсорной, двигательной сферы, причиной которых являются органические поражения структур головного мозга; семьи, воспитывающие детей, находящихся в пограничном состоянии (с задержкой психического развития, высоким уровнем социальной и педагогической запущенности; склонностью к проявлениям девиантного поведения, имеющих характерологические или поведенческие отклонения).

При планировании комплекса мероприятий, направленных на профилактику неоптимальных моделей семейного воспитания, осуществление индивидуальной работы с вышеперечисленными типами семей рекомендуется оказывать содействие в проведении тематических консультаций для детей и родителей (законных представителей): социального педагога, психолога, юриста, дефектолога, детского невропатолога, психоневролога, логопеда, детского психиатра; оказывать психолого-педагогическую помощь в социальном и профессиональном самоопределении детям с проблемами развития; способствовать направлению детей с проблемами психофизического развития в группы социальной и психологической коррекции, использующих методики арттерапии, эмаготерапии, ипотерапии, игротерапии, сказкотерапии и т. д.; содействовать в определении детей с ОВ3 в специализированные учреждения системы социальной защиты, образования, здравоохранения для реабилитации, лечения и обучения; оказывать родителям (законным представителям) и детям, имеющим отклонения в психосоматическом развитии правовую, помощь по защите их прав; содействовать родителям (законным представителям), имеющим детей с ОВ3, в получении на льготных условиях инвалидных колясок, медикаментов и т.п.; оказывать содействие в выявлении потенциальных творческих способностей детей с проблемами развития, способствовать их целенаправленному развитию в кружках, студиях, секциях учреждений дополнительного образования; проводить для детей с OB3 коллективные воспитательные дела с целью социальной реабилитации и адаптации, создания благоприятного эмоционального настроя.

Четвертый вариант подхода к классификации проблемных семей, воспитывающих детей с ОВ3 включает несколько различных подходов к классификации семей по различным основаниям, однако, все они отражают различные аспекты оптимальных и неоптимальных взаимоотношений между родителями (законными представителями) и детьми, а также их характер отношений с социумом.

Оптимальными взаимоотношениями могут считаться те, в которых взрослые члены семьи: сосредоточиваются на позитивных сторонах и преимуществах ребёнка с ОВ3 с целью укрепления его самооценки; помогают ребёнку с ОВ3 поверить в себя и свои способности; помогают ребёнку с ОВ3 избежать ошибок, а при их свершении способны найти лучший вариант для их исправления; поддерживают ребёнка с ОВ3 при неудачах, оказывая ему конкретную действенную помощь и поддержку.

Именно такие взаимоотношения присущи семьям с высоким уровнем нравственного потенциала, педагогически компетентным в вопросах семейного воспитания, в которых преобладает демократический стиль взаимоотношений между её членами.

\section{ЛИТЕРАТУРА}

1. Инклюзивное образование. Настольная книга педагога, работающего с детьми с ОВЗ [Текст]. - М.: Владос, 2013. - 168 с.

2. Дементева Н.Ф. Социальная работа с семей ребенка с ограниченными возможностями. - М.: Институт социальной работы, 1996.

3. Кузьмичева, Т.В. Психолого-педагогическая парадигма профессионального образования лиц с ОВЗ [Текст] / Т.В. Кузьмичева, Ю.А. Афонькина // Проблемы современного педагогического образования. - 2018. № 60-4. - С. 242-245 
4. Лёвина Т.В. Семейное воспитание ребенка с отклонениями в развитии [Электронный ресурс] / Т.В. Лёвина. - Режим доступа: http://nsportal.ru/shkola/ psikhologiya/library/2014/03/26/semeynoe-vospitanie-i-obrazovanie-detey-s-ovz

5. Ткачева В.В. Психологическое изучение семьи, воспитывающей ребенка с нарушениями развития // Психолого-педагогическая диагностика: Учеб. пособие для студентов высш. пед. учеб. заведений / Под ред. И.Ю. Левченко, С.Д. Забрамной. М.: Изд.центр «Академия», 2003.

6. Федосеева 0.А. Особенности воспитания ребенка с ограниченными возможностями в семье // Молодой ученый. -- 2013. -- №9. -- С. 346-349.

7. 06 образовании в Российской Федерации: федер. закон от 29.12.2012 №273-Ф3 [Электронный ресурс]: Справочно-правовая система КонсультантПлюс (дата обращения: 28.09.2019).

(c) Дохоян Анна Меликсовна (d.a.m@mail.ru).

Журнал «Современная наука: актуальные проблемы теории и практики»

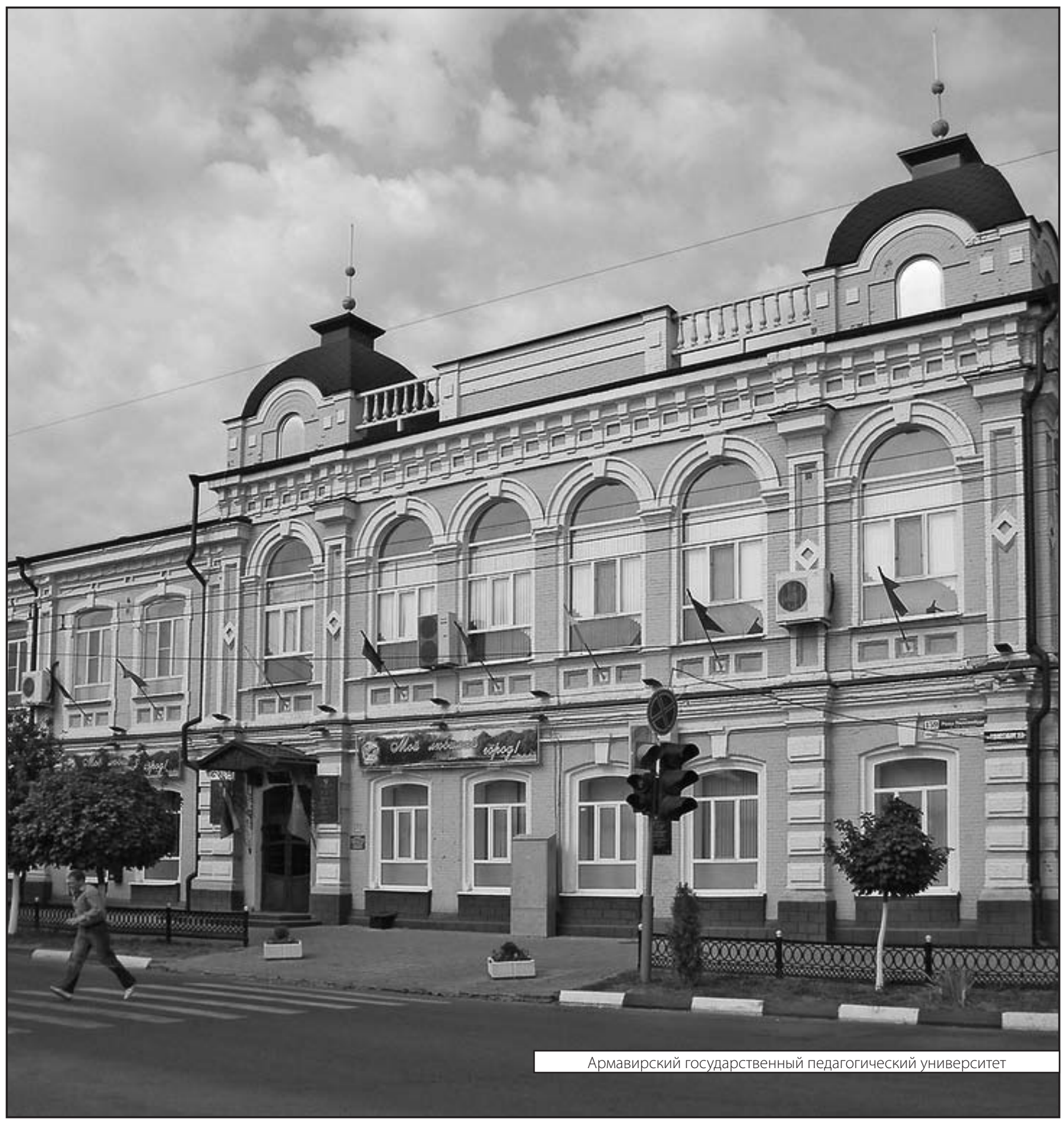

